\title{
Impact of Irrigation with Drainage Water on the Productivity of Forage Maize Grown on Calcareous Soil
}

\author{
Saad A E Abdelrazek ${ }^{1}$, Ahmed. E.M. Shouman ${ }^{2}$, Mohamed H.El-Deep ${ }^{3}$, Waleed. M. B. Darwisch ${ }^{4}$
}

\begin{abstract}
A greenhouse experiment was conducted to mitigate the deterious effect of drainage water on growth and nutrient uptake of forage maize grown on Borg ElArab calcareous soil. The soil has high $\mathrm{CaCo}_{3}$ content and irrigated with well water $(22.5 \%)$ and drainage water $(27.5 \%)$. This practice increased calcium carbonate content in soils and increased electric conductivity values to $3.65 \mathrm{dS} / \mathrm{m}$ and $9.30 \mathrm{dS} / \mathrm{m}$ in soils irrigated with well water and drainage water, respectively. The obtained results indicated that the saline water have a significant effect on maize fodder, silage quality and maize plant, seed weight, plant height, root / shoot ratio.

The forage maize and maize silages yield were significantly reduced at different irrigation water treatments. The forage yield, silages index and forage index (\%) also significantly reduced. The mean forage index was found to be $0 . \mathbf{3 6}$ and was not affected by well water salinity level. In addition, the results showed that, the maize silages with lower content of crude fiber are considered as important energy source for feeding. The content of acetic acid was lower in silages at different salinity levels and the values were $25.34,21.33,11.27$ and 11.27 $S_{0}, S_{1}, S_{2}$ and $S_{3}$. Direct cause for reduction of maize silages quality was the higher content of acetic acid.
\end{abstract}

Keyword: saline water, forage maize, maize silages, calcareous soil

\section{INTRODUCTION}

Salinity is the major environmental stress and is a substantial constraint to crop production. Soil salinity is one of the major factors limiting plant growth and productivity (Bohnert and Jensen, 1996; Munnus, 2002; Abdelrazek S. A. E. 2014). Excessive accumulation of salt ions, mainly $\mathrm{Na}$ and $\mathrm{Cl}$ ions in the leaves is the major contributory factor (Hajibagheri et al., 1989).

High sodium concentration in particular which deposit in the soil can alter the basic texture of the soil resulting in decreased soil porosity and consequently reduced soil aeration and water conductance (Mahajan

\footnotetext{
${ }^{1}$ Soil Salinity Department, Alexandria Soil, Water and Environment

Research Institute, Agriculture Research Center (ARC), Giza, Egypt

${ }^{2}$ Institute of Environment Studies Research -Ain Shams University,

Cairo, Egypt

${ }^{3}$ Department of Horticulture, Faculty of Agriculture,

Ain Shams University, Cairo, Egypt

${ }^{4}$ Department of natural resources Evaluation, planning and development

Environmental Studies and Researches Institute, Sadat City University,

Sadat, Egypt

Corresponding author S.A.E. Abdelrazek

Email: Samad_saad@yahoo.com

Received July 25, 2016, Accepted August 25, 2016
}

and Tuteja, 2005). The saline growth medium causes many adverse effects on plant growth, which are due to a low osmotic potential of the soil solution (osmotic stress), specific ion effect (salt stress), nutritional imbalances or a combination of these factors (Hassanein, 2000; Ashraf, 2004).

The decrease in plant length, leaf area and number of leaves due to the increase in concentration of sodium chloride was recorded (Rui et al., 2009: Memon et al., 2010).

Many studies have shown that the fresh and dry weights of the shoot system are affected, either negatively or positively, by changes in salinity levels (Memon et al., 2010 and Hashem et al., 2013). Also, other studies confirmed the inhibitory effect of salinity on biochemical processes, such as photosynthetic process.

Forage maize is one of the most important crops in Egypt agriculture, where the irrigation is required throughout the year, mainly in semi-arid areas. The waters used for irrigation in these areas, especially well waters, are frequently saline and/or alkaline, with high concentration of $\mathrm{Cl}^{-}$and, to a lesser extent, $\mathrm{Na}^{+}$(Katerji et al., 2001; Yazar et al., 2003).

The objective of this study was: to mitigate the deterious effect of saline drainage water as saline water on growth and nutrient uptake of forage maize grown on calcareous soil.

\section{MATERIALS AND METHODS}

\section{I- Experimental Layout}

The experiment was conducted in a greenhouse of in Soil Salinity and alkalinity Laboratory, Alexandria.

Experimental design was a randomized complete block design with four treatments and three replications. The treatments were well water as control treatment $\left(\mathrm{S}_{0}\right)$, one third drainage water mixed with two third well water $\left(\mathrm{S}_{1}\right)$ two, third drainage water mixed with 
one, third well water $\left(\mathrm{S}_{2}\right)$ and only drainage water $\left(\mathrm{S}_{3}\right)$. The plants were sown in plastic pots.

The pots were $35(\mathrm{~d}) \times 80(\mathrm{~L}) \mathrm{cm}$ dimensions and were placed in open space and filled with Borg El Arab soil.

The Borg El Arab soil was irrigated with drainage water since years ago. The control treatments soil represents adjacent farms irrigated with well water and had the same physical and chemical properties of Borg El Arab soil.

Soil samples of both regions were taken from depth of $0-40 \mathrm{~cm}$ and salinity were assayed. Seed of forage maize were sown (Single hybrid Shandaweel-1).

The fertilizer requirements of forage maize were added in the form of superphosphate (OSP) (15\%) and up to $(10-15 \mathrm{~kg} / \mathrm{ha})(8-12$ units/ ha) of the nitrogen $(\mathrm{N})$ in the form of Urea $\mathrm{NH}_{2}-\mathrm{CO}-\mathrm{NH}_{2}(46 \%)$ required and $(\mathrm{K})$ in the form of potassium sulfate $\mathrm{K}_{2} \mathrm{SO}_{4}(50-52 \%)$ $\mathrm{K}_{2} \mathrm{O}$.

In each pot when fourth leaf was appeared, the plants were thinned to three plants. Irrigation water was supplied from the upstream channel and transferred to the site of study by tank. In control treatments the pots were irrigated by well water.

The pots were irrigated every week at early period of plant growth after that the plants were irrigated three times a week.

After 14 weeks, from each treatment three plants were sampled.

The roots were removed from soil and then roots were cleaned by hand.

Samples were washed several times by tap water and then were washed with distilled water at room temperature and then were completely dried in the oven at $70^{\circ} \mathrm{C} / 48 \mathrm{hrs}$. The dried plant samples were dry as had in muffle furnace at $500{ }^{\circ} \mathrm{C}$, and then the ash was dissolved in nitric acid (Jones, 2001)

Concentrations of elements were analyzed by Atomic Absorption model PYE Unicam SP9

\section{II- WATER SAMPLES}

Well and drainage water samples were taken and stored in clean glass bottles (WPCE, 1998) for the analysis of the major contents of water. The water samples were analyzed according to the following methods:

$\mathrm{pH}$ was measured using Beckman's $\mathrm{pH}$ meter (Jackson, 1958). Electrical conductivity was measured (EC dS/m) using conductometer (Jackson, 1958).

Soluble cation and anion were according to (Page et al., 1982).
SAR (Sodium Adsobtion Ratio) was calculated as:

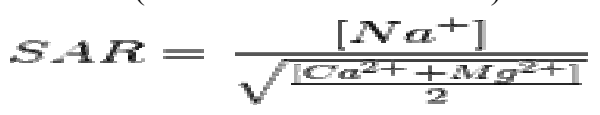

Where $\mathrm{Na}^{+}, \mathrm{Ca}^{++}$and $\mathrm{Mg}^{++}$refer to their concentrations in meq/l (Donahue et al., 1990)

\section{III - SOIL SAMPLING}

The soil samples were analyzed according to the following methods:

Soil bulk density was determined using core sampler, as described by (Richards, 1954)

Soil hydraulic conductivity $(\mathrm{K} \mathrm{cm} / \mathrm{hr})$ was determined using the constant head test for disturbed coarse textured soils as described by (Baruah and Barthakur, 1997)

Mechanical analysis was determined using the pipette method, as cited by (FAO, 1970)

Electrical conductivity (EC $\mathrm{dS} / \mathrm{m})$ of the saturated soil extracts using a conductometer (Jackson, 1958).

Soil reaction $(\mathrm{pH})$ of the saturated soil paste was determined using Beckman's pH meter (Jackson, 1958).

Total carbonate content was estimated volumetrically by Collin's calcimeter (Williams, 1948).

The soil physical and chemical analyses are presented in Tables $(3,4)$

\section{IV- Quality of Silage}

The parameter quality of maize silages was determined in Central Laboratory for Food and Feed Ministry of Agriculture as follows.

Content of dry matter (DM) we determined by drying of sample to constant weight by temperature $103 \pm 2{ }^{\circ} \mathrm{C}$ (predrying by $\mathrm{t} 60{ }^{\circ} \mathrm{C}$ ) (Ferreira, 2002). Content of nitrogen free extract (NFE) and organic matter $(\mathrm{OM})$ were calculate $(\mathrm{NFE}=$ dry matter-crude protein-crude fiber-fat-ash, $\mathrm{OM}=$ dry matter-ash) (Mertens, D.R. 2005). Crude protein was measured using the micro-Kjeldahl method, crude fat extraction by light petroleum (Ferreira, and Mertens 2005).

Ash was determined by combustion in a muffle furnace at $550{ }^{\circ} \mathrm{C}$. Starch was determined by polarimetric method (Ferreira, and Mertens 2005). Crude fiber was determined gravimetrically as the residue remaining after extraction in acid and alkali (Ferreira, 2002).

Lignin content was determined gravimetrically according to (Dhiman et al., 2005) fiber content was determined gravimetrically as the residue remaining after extraction (Dhiman et al., 2005).

Neutral detergent fiber: gravimetrically as the residue remaining after extraction in neutral detergent solution (Dhiman et al., 2005) 
Energy (NEL, NEG) and protein values (PDI) were calculated by regression Equations. Silage extracts were prepared from $200 \mathrm{~g}$ of sample and $2000 \mathrm{ml}$ of distilled water, after 20 hours staining, contents of fermentation acids (formic, lactic, acetic, butyric, propionic) were extracted using the ionic electrophoresis method. Active acidity was determined by electrometric method. Fermentation products were calculated by count of fermentable acids without alcohols (Ferreira, and Mertens 2005).

\section{Forage index \%}

The metabolisable energy (ME) concentration trait is quantified as the megajoules of metabolisable energy per kilogram of dry matter (MJME/kg DM) (Ludemann et al., 2015)

Forage index $\%=\mathrm{ME} /$ dry matter

\section{Statistical analysis}

The experiment utilized a completely randomized design. Mean values were calculated from measurements of five replicates and standard deviations of the means were calculated. All data were subjected to Duncan's multiple range tests to discriminate significance (defined as $p<0.05$ ). All data were analyzed statistically by one-way analysis of variance using the SPSS program (version 18.0) (Duncan, 1955).

\section{RESULTS AND DISCUSSIONS}

The properties of water samples were presented in Tables (1\&2)

Table (1) shows the EC of Well and drainage water $(1.56 \mathrm{dS} / \mathrm{m}$ and $4.92 \mathrm{dS} / \mathrm{m})$, respectively.

The electrical conductivity of the irrigation water (EC) affected most variables related to the growth of maize plants Table (1).

In addition, there was a significant difference among treatments in $\mathrm{Zn}$ content in leaves and soil. In addition, the results showed significant difference among treatments in $\mathrm{P}$ and $\mathrm{K}$ concentrations in leaves (Fig 1) because of high level of these elements in drainage water (Table 2). Also there was significant difference among treatment in $\mathrm{Fe}$ accumulation in soil and water (Tables 2\& 4).

Table (3) Shows that EC values were $3.65 \mathrm{dS} / \mathrm{m}$ and $9.30 \mathrm{dS} / \mathrm{m}$ in soils irrigated with well and drainage water respectively. This management practice causes secondary salinization in soils. These results coincided with the result of (El-Gabaly 1971)

Table 1. Chemical analysis and quality classes of irrigation water used in this study

\begin{tabular}{|c|c|c|c|c|c|c|c|c|c|c|c|}
\hline \multirow{3}{*}{$\begin{array}{l}\text { Irrigation } \\
\text { water }\end{array}$} & \multirow[t]{3}{*}{ pH } & \multirow{3}{*}{$\begin{array}{c}\mathrm{EC} \\
\mathrm{dS} / \mathrm{m}\end{array}$} & \multicolumn{4}{|c|}{ Soluble cations } & \multicolumn{4}{|c|}{ Soluble anions } & \multirow{3}{*}{$\begin{array}{l}\text { Quality } \\
\text { classes }\end{array}$} \\
\hline & & & \multicolumn{8}{|c|}{ meq / L } & \\
\hline & & & $\mathbf{N a}$ & $\mathbf{K}$ & $\mathbf{C a}$ & Mg & $\mathrm{HCO}_{3}$ & $\mathbf{C l}$ & $\mathrm{SO}_{4}$ & SAR & \\
\hline Well water & 8.52 & 1.56 & 8.30 & 0.38 & 1.90 & 1.96 & 5.10 & 4.82 & 2.62 & 4.89 & $\mathrm{C} 3-\mathrm{S} 2$ \\
\hline Drainage water & 8.81 & 4.92 & 19.40 & 0.15 & 6.10 & 6.82 & 2.50 & 15.90 & 14.08 & 6.29 & $\mathrm{C} 4-\mathrm{S} 2$ \\
\hline $\begin{array}{l}\text { Permitted level } \\
\text { for irrigation } \\
\text { FAO guidelines } \\
1976\end{array}$ & $6.5-8.4$ & $<3$ & $<70$ & $===$ & $==$ & $==$ & $<90$ & $<140$ & $==$ & $<9.0$ & \\
\hline
\end{tabular}

$\mathrm{C}_{3}$ : high salinity and $\mathrm{C}_{4}$ : very high salinity, $\mathrm{S}_{2}$ : medium alkalinity

Table 2. Some trace element of water used in this study

\begin{tabular}{lccccccc}
\hline \multirow{2}{*}{ Irrigation water } & $\mathbf{N}$ & $\mathbf{P}$ & $\mathbf{K}$ & $\mathbf{M n}$ & $\mathbf{F e}$ & $\mathbf{C u}$ & $\mathbf{Z n}$ \\
\cline { 2 - 8 } & $\mathbf{\%}$ & & \multicolumn{2}{c}{$\mathbf{m g . k g}^{-1}$} & & \\
\hline Well water & $\mathbf{N D}$ & $\mathbf{N D}$ & $\mathbf{N D}$ & $\mathbf{N D}$ & $\mathbf{N D}$ & Trace & $\mathbf{N d}$ \\
\hline Drainage water & 0.1 & 0.1 & 0.02 & 108.4 & 142.9 & 0.05 & 1.7 \\
\hline $\begin{array}{l}\text { Permitted level for } \\
\text { irrigation }\end{array}$ & 5 & $\mathrm{Nd}$ & $\mathrm{Nd}$ & 0.2 & 5 & 0.2 & 2 \\
\hline
\end{tabular}

ND: not detected

Table 3. Some chemical characteristics of the soil used in this study after irrigation

\begin{tabular}{lcccccccccc}
\hline $\begin{array}{l}\text { Irrigation } \\
\text { water }\end{array}$ & $\mathbf{p H}$ & $\mathbf{E C}$ & \multicolumn{3}{c}{ Soluble cations meq / } & \multicolumn{3}{c}{ Soluble anions $\mathbf{~ m e q} / \mathbf{L}$} & $\mathbf{S A R}$ \\
\cline { 2 - 11 } & & $\mathbf{d S} / \mathbf{m}$ & $\mathbf{C a}^{++}$ & $\mathbf{M g}^{++}$ & $\mathbf{N a}^{+}$ & $\mathbf{K}^{+}$ & $\mathbf{H C O}_{\mathbf{3}}^{--}$ & $\mathbf{C l}^{-}$ & $\mathbf{S O}_{\mathbf{4}}^{--}$ \\
\hline $\begin{array}{l}\text { Control } \\
\text { Well water) }\end{array}$ & 8.68 & 3.65 & 2.75 & 1.51 & 13.78 & 0.58 & 2.12 & 12.41 & 4.08 & 9.37 \\
\hline $\begin{array}{l}\text { Drainage } \\
\text { water }\end{array}$ & 8.68 & 9.30 & 14.88 & 10.00 & 85.40 & 3.62 & 3.30 & 84.66 & 25.94 & 21.08 \\
\hline
\end{tabular}


Table 4. Fertility characteristic of soil used in this study before irrigation

\begin{tabular}{lccccccccc}
\hline Irrigation water & $\mathbf{N}$ & $\mathbf{P}$ & $\mathbf{K}$ & $\mathbf{M n}$ & $\mathbf{F e}$ & $\mathbf{C u}$ & $\mathbf{Z n}$ & $\mathbf{C a C O}_{\mathbf{3}}$ & Texture \\
\cline { 2 - 12 } & \multicolumn{2}{c}{$\mathbf{\%}$} & \multicolumn{2}{c}{$\mathbf{m g . k g}^{-\mathbf{1}}$} & & $\mathbf{( \% )}$ & \\
\hline Control (Well water) & 0.04 & 5.7 & 399 & 785.2 & 209.2 & 27.9 & 77 & 22.5 & SCL \\
\hline Drainage water & 0.19 & 9.6 & 282 & 796.5 & 269.3 & 34.5 & 69.8 & 27.5 & SCL \\
\hline
\end{tabular}

SCL: Silt Clay Loam

Table 5. Effect of different waters on metal concentrations in soil after irrigation ( $\left.\mathrm{mg}^{\mathrm{kg}} \mathrm{kg}^{-1}\right)$

\begin{tabular}{|c|c|c|c|c|}
\hline \multirow[t]{2}{*}{ Treatments } & $\mathrm{Cu}$ & Mn & $\mathbf{F e}$ & Zn \\
\hline & \multicolumn{4}{|c|}{ mg.kg ${ }^{-1}$} \\
\hline $\mathrm{S}_{0}$ & 47.14 & 528.67 & 24.650 & 51.232 \\
\hline $\mathrm{S}_{1}$ & 56.72 & 874.12 & 6623.96 & 128.00 \\
\hline $\mathrm{S}_{2}$ & 41.57 & 768.52 & 1952.00 & 65.13 \\
\hline $\mathrm{S}_{3}$ & 50.74 & 943.41 & 5199.61 & 118.99 \\
\hline
\end{tabular}

$\mathrm{S}_{0}$ : Control (well water) $\mathrm{S}_{1}$ : Drainage water and well water $(1: 2) \mathrm{S}_{2}$ : Drainage water and well water $(2: 1) \mathrm{S}_{3}$ : Drainage water

Table 6. Effect of different Drainage water in maize plant ( $\left.\mathrm{mg}^{\mathrm{kg}} \mathrm{kg}^{-1}\right)$

\begin{tabular}{lccccccc}
\hline Treatments & $\mathbf{N}$ & $\mathbf{P}$ & $\mathbf{K}$ & $\mathbf{C u}$ & $\mathbf{M n}$ & $\mathbf{F e}$ & $\mathbf{Z n}$ \\
\hline $\mathrm{S}_{0}$ & $1.26 \mathrm{a}$ & $0.28 \mathrm{a}$ & $3.576 \mathrm{a}$ & $12.68 \mathrm{a}$ & $47.58 \mathrm{a}$ & $443.8 \mathrm{a}$ & $29.59 \mathrm{~b}$ \\
\hline $\mathrm{S}_{1}$ & $1.82 \mathrm{a}$ & $0.25 \mathrm{a}$ & $2.973 \mathrm{a}$ & $14.69 \mathrm{a}$ & $44.58 \mathrm{a}$ & $351.07 \mathrm{a}$ & $36.48 \mathrm{ab}$ \\
\hline $\mathrm{S}_{2}$ & $1.46 \mathrm{a}$ & $0.14 \mathrm{a}$ & $2.186 \mathrm{a}$ & $11.64 \mathrm{a}$ & $41.50 \mathrm{a}$ & $312.32 \mathrm{a}$ & $31.85 \mathrm{a}$ \\
\hline $\mathrm{S}_{3}$ & $0.28 \mathrm{a}$ & $0.15 \mathrm{a}$ & $1.863 \mathrm{a}$ & $4.64 \mathrm{a}$ & $38.68 \mathrm{a}$ & $265.18 \mathrm{a}$ & $24.87 \mathrm{~b}$ \\
\hline
\end{tabular}

Within each column followed by the same letter are not significantly differences $(p<0.05)$

$\mathbf{S}_{\mathbf{0}}$ : Control (well water) $\mathbf{S}_{\mathbf{1}}$ : Drainage water and well water (1:2) $\mathrm{S}_{2}$ : Drainage water and well water (2:1) $\mathbf{S}_{3}$ : Drainage water

Table (4) illustrated that $\mathrm{CaCo}_{3}$ content are higher in soils irrigated with well water $(22.5 \%)$ and drainage water $(27.5 \%)$. This practice may increase calcium carbonate content in soils and increase area of calcareous soils (Balba, 1981).

Trace element concentrations were significantly increased in leaves of maize plants irrigated with well and/ or drainage waters. This was due to high concentration of trace elements in irrigation water sources (Table 6 and Fig 1). These results coincided with the results of Gaui, et al., (1997)

The first effect of salts is reducing the ability of plants to absorb water (osmotic effect), which leads to slower growth; second, salts may enter the transpiration stream and injure leaf cells, further reducing growth (Munns, 2005 and Mohamed Fattah and Abdelrazek, 2014).

The high concentration of $\mathrm{Na}^{+}$and $\mathrm{Cl}^{-}$in soil solution is generally the main cause of the saline stress (Hasegawa et al., 2000) and the consequent slower growth is an adaptive feature for plant survival because it allows plants to rely on multiple resources to combat stress.

Using the $1.56 \mathrm{dS} \mathrm{m}^{-1}$ treatment as reference, the seed weight and plant height was higher than the 100 $\mathrm{cm}$ per plant (well water) found by (Hasegawa et al., 2002) and are in agreement with (FAO, 1973) who found seed weight and plant height values varying from
112 to $181 \mathrm{~cm}$ per plant for different hybrids (Table 7). In contrast for $4.92 \mathrm{dS} \mathrm{m}^{-1}$ (drainage water), plant height recorded $127.38 \mathrm{~cm}$.

But $154 \mathrm{~cm}$, which was lower than $188 \mathrm{~cm}$, was recorded by Katerji et al., (2001).

There were expected differences of root to shoot ratio because the root to shoot ratio depends on several variables like soil fertility, meteorological conditions, plant density and genetic characteristics of cultivars and hybrids (FAO 1973).

The salinity of irrigation water delayed the growth of plants, with reduction of the root to shoot ratio (Table 7)

Irrigation with saline water did not supply nutritional elements and thus not improved plant growth characteristics. Studying the effects of water salinity on maize, showed that, there was significant difference among treatments in plant dry weight, root weight, stem weight, plant height, seed weight and root to shoot ratio at 0.01 probability level (Table 7). Comparison of means related saline water that application significantly decreased plant height, seed weight, root weight, stem weight and total plant weight (Fig 2). Decrease of root volume as results of saline water application can be due to direct effects of organic substances in wastewater (Fig 2). 

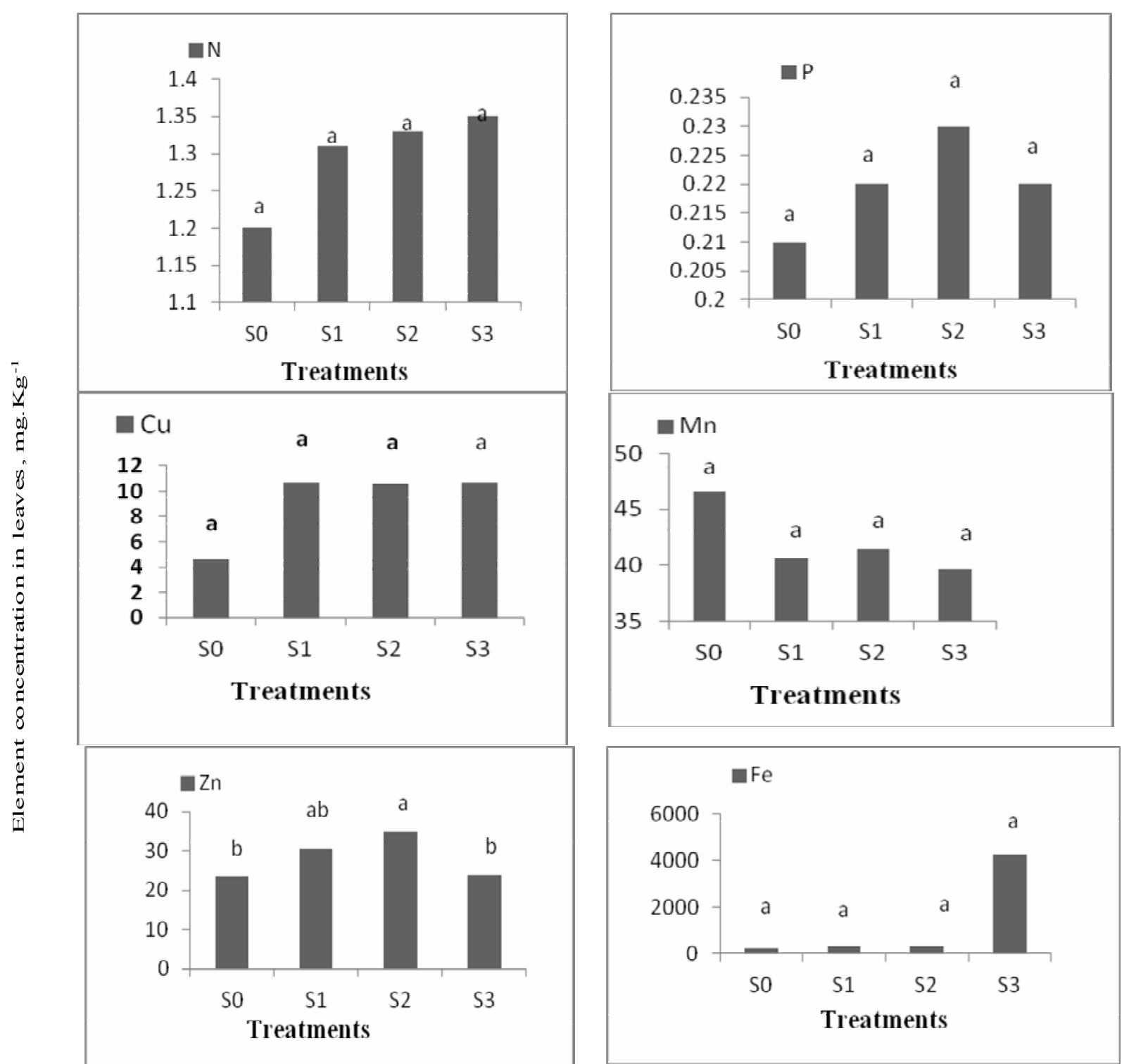

Fig 1. Effect of different drainage water on elements $N(\%), P, K\left(\mathrm{mg}^{-k^{-1}}\right)$ and salinity in maize plant

Table 7. Effect of Drainage water on morphological traits of maize

\begin{tabular}{lccc}
\hline Treatments & $\begin{array}{c}\text { Seed weight } \\
(\mathbf{g})\end{array}$ & $\begin{array}{c}\text { Plant height } \\
(\mathbf{c m})\end{array}$ & Root / shoot ratio \\
\hline $\mathrm{S}_{0}$ & $18.59 \mathrm{a}$ & $225.54 \mathrm{a}$ & $0.350 \mathrm{a}$ \\
\hline $\mathrm{S}_{1}$ & $17.90 \mathrm{a}$ & $189.97 \mathrm{a}$ & $0.189 \mathrm{a}$ \\
\hline $\mathrm{S}_{2}$ & $17.87 \mathrm{a}$ & $182.06 \mathrm{a}$ & $0.185 \mathrm{a}$ \\
\hline $\mathrm{S}_{3}$ & $6.98 \mathrm{~b}$ & $127.38 \mathrm{~b}$ & $0.145 \mathrm{~b}$ \\
\hline
\end{tabular}

Within each column followed by the same letter are not significantly differences $(p<0.05)$

S0: Control (well water) $\mathrm{S}_{1}$ : Drainage water and well water (1:2) $\mathrm{S}_{2}$ : Drainage water and well water (2:1) $\mathrm{S}_{3}$ : Drainage water 


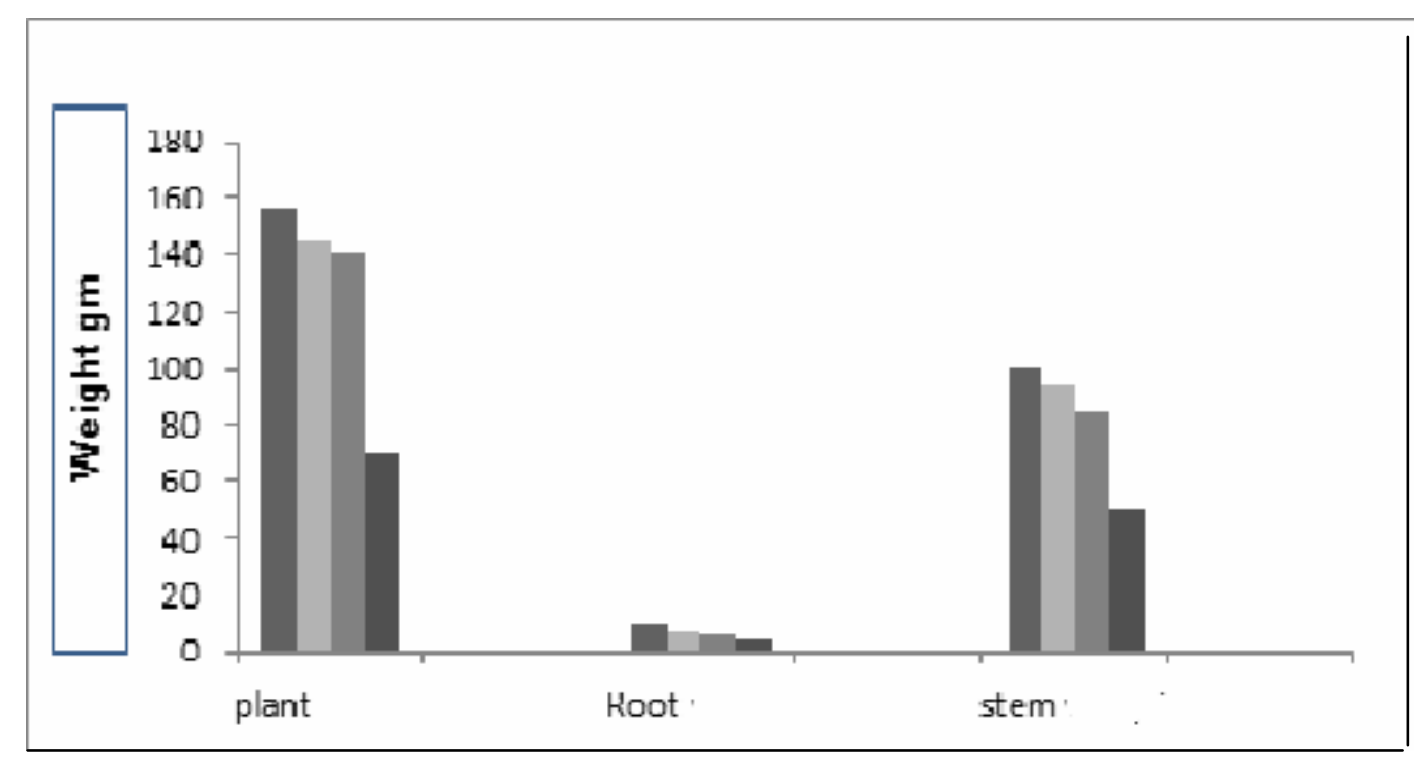

Fig. 2. Effect of different irrigation waters on dry weight of maize plant tissues

The large amount of salts introduced to soil after irrigation with drainage water reduced the yield and sometime makes impossible for crop production. Once the soils are saline the recommended method for reclamation is leaching the soils and providing the drainage facilities and controlling these factors responsible for secondary salinization of soil. This is widely used practice in many parts of the world. But the success of leaching depends upon the quality of leaching water, amount and kind of salts and their distribution in the soil profile and water movement properties of soils. Mahdy et al., (2012) suggested that antioxidants can improve growth and nutrients content of corn plants grown under moderate to high salinity and/or water deficit stresses.

On the other side Fathi and Goafer, (2015) revealed, to seed priming technique in saline media to increase germination and early growth of corn seeds.

The cultivated area of forage maize (Nile and summer season) $222.531 \mathrm{fed}(93.461 \mathrm{Ha})$

The nutritional value of $4 \mathrm{~kg}$ maize silage equal one $\mathrm{kg}$ feed so, must if you use $50 \%$ of silage in the feed provided by the combination may help in reducing the cost in the range of $20-25 \%$.

In Table (7) illustrated the forage maize and maize silages yield $\left(\right.$ Ton $\mathrm{Fed}^{-1}$ ) at different irrigation water treatments.

The EC reduced forage yield, silages index and forage index $\%$ (Table 8 ). The mean forage index $\%$ was found to be 0.36 and was not affected by well water salinity level. This is in accordance with (Yazar et al., 2003)

For maximization maize, silage production, early planting and adequate populations, soil fertility, row spacing, hybrids, crop rotations, soil management and dry matter measurements at harvest are necessary (Tenison 2007, 2009)

Salinity negatively affects the root distribution and thus affects the plant's ability to use the elements

Accumulation of macro and micro elements in plant tissues after irrigation with well and / or drainage water revealed that irrigation water treatment significantly affected concentration of element in soil and plant (Table 5 \& 6)

Table 8. Effect of Drainage water on maize plant productivity

\begin{tabular}{|c|c|c|c|c|}
\hline Treatments & $\begin{array}{l}\text { forage maize yield } \\
\left(\text { TonFed }^{-1}\right)\end{array}$ & $\begin{array}{c}\text { maize silages yield } \\
\left(\text { TonFed }^{-1}\right)\end{array}$ & $\begin{array}{c}\text { forage index } \\
\%\end{array}$ & $\begin{array}{c}\text { silages index } \\
\%\end{array}$ \\
\hline $\mathrm{S}_{0}$ & 12 & 18 & 36 & 67.3 \\
\hline $\mathrm{S}_{1}$ & 9 & 15 & 28 & 52.4 \\
\hline $\mathrm{S}_{2}$ & 6.5 & 11 & 20 & 27.3 \\
\hline $\mathrm{S}_{3}$ & 5 & 9.5 & 15 & 28 \\
\hline L.S.D & 1.6 & 3.3 & -- & 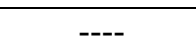 \\
\hline
\end{tabular}


Table 9. Bio concentration factor of some elements and salinity from soil to maize plant under salinization

\begin{tabular}{lcccc}
\hline Treatments & $\mathbf{C u}$ & Mn & Fe & Zn \\
\hline $\mathrm{S}_{0}$ & 0.269 & 0.09 & 0.18 & 0.577 \\
\hline $\mathrm{S}_{1}$ & 0.259 & 0.051 & 0.053 & 0.285 \\
\hline $\mathrm{S}_{2}$ & 0.28 & 0.054 & 0.16 & 0.489 \\
\hline $\mathrm{S}_{3}$ Maize standard & 0.19 & 0.041 & 0.051 & 0.209 \\
\hline
\end{tabular}

$\mathrm{S}_{0}$ : Control (well water) $\mathrm{S}_{1}$ : Drainage water and well water $(1: 2) \mathrm{S}_{2}$ : Drainage water and well water (2:1) $\mathrm{S}_{3}$ : Drainage water

Bio concentration factor $=$ microelement value in plant $/$ microelement value in soil

The accumulation of trace elements, bio concentration factor $(\mathrm{BCF})$ of some elements from soil to maize plant under salinization are presented in Table (9) BCF of $\mathrm{Cu}$ were $0.269,0.28,0.259$ and 0.19 , For Mn 0.09, 0.054, 0.051 and 0.041, For Fe 0.18, 0.16,

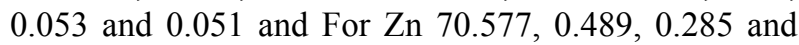
0.209 at S0, S2 and S1 and finally S3 treatments, respectively Table (9).

Bio-concentration factor in Table (9) was calculated from Table (5) and Table 6 had illustrated effect of different drainage water in maize plant and soil.

\section{The quality of maize silages}

Salinity is abiotic factor that limiting plant growth, productivity and quality of maize silages.

Dry matter (DM) content of maize silage depends greatly on the maturity of the maize at time of harvest often reflecting the proportion and development of kernels in the silage (Kolver et al., 2001). Maize silage provides important source of energy in the form of starch and fibre fractions for dairy cattle sheep nutrition (USDA, 2013). In the present study the average dry matter content (157.87g. $\mathrm{kg}^{-1}$ ) was recorded at So (Table 10).
Also, the highest was observed at so starch (341.90) content of acid detergent fiber and neutral detergent fiber were observed at So. The value of net energy of maize silage were very similar $(5.36,4.21,3.22$. and 5.37) at $\mathrm{S} 0, \mathrm{~S}_{1}, \mathrm{~S}_{2}$, and $\mathrm{S} 3$ respectively

In comparison with silages produced maize plants irrigation with different water from these treatments, lower content of ash in silages was observed at $S_{2}$ (12.6) Thus, it should be taken to consideration that these types of water can be used to produce safety silages material has high quality and productivity Table 10 these result reached by(Bosworth, 2006) It is reported that all maize silages with lower content of crude fiber are considered as important energy source crop for feeding (Jung et al 1998). The silage hybrid, dry matter content, addition of additives technological silage making and method of unloading silage affects the quality of maize silage (summers, 2001)

Content of acetic acid was lower in silages at different salinity levels and the values were 25.34, $21.33,17.21$ and $11.27 \mathrm{~S}_{0}, \mathrm{~S}_{1}, \mathrm{~S}_{2}$, and $\mathrm{S}_{3}$ respectively (Table 12). Direct cause for reduction of maize silages quality was higher content of acetic acid (Biro, 2002).

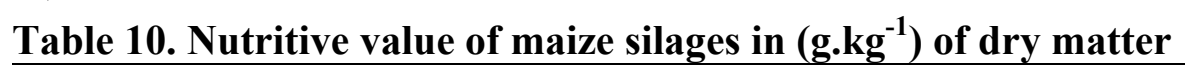

\begin{tabular}{lccccc}
\hline \multicolumn{1}{c}{ Treatments } & $\mathbf{S}_{\mathbf{0}}$ & $\mathbf{S}_{\mathbf{1}}$ & $\mathbf{S}_{\mathbf{2}}$ & $\mathbf{S}_{\mathbf{3}}$ \\
\hline \multicolumn{7}{c}{ parameters } \\
\hline \multicolumn{7}{c}{$\mathbf{x}$} \\
\hline dry matter & 157.87 & 140.00 & 112.86 & 94.30 & 3.30 \\
\hline crude protein & 85.65 & 65.98 & 35.86 & 0.94 & 0.84 \\
\hline crude fat & 36.17 & 37.52 & 20.8 & 19.80 & 0.40 \\
\hline crude fiber & 199.57 & 27.78 & 16.98 & 177.52 & 0.75 \\
\hline acid detergent fiber & 247.97 & 234.9 & 112.9 & 239.16 & 45.60 \\
\hline neutral detergent fiber & 422.61 & $123 \mathrm{~L} 8$ & 119.8 & 410.34 & 38.71 \\
\hline ash & $29.75^{*}$ & 16.86 & 12.6 & $25.38^{*}$ & 1.93 \\
\hline nitrogen free extract & $669.80^{*}$ & 99.4 & 87.8 & $569.90^{*}$ & 3.95 \\
\hline starch & 341.90 & 143.8 & 131.9 & 234.61 & 28.66 \\
\hline organic matter & $890.15^{*}$ & 782.78 & 699.98 & $870.15^{*}$ & 1.47 \\
\hline S: Cont & & & & \\
\hline
\end{tabular}

$\mathrm{S}_{0}$ : Control (well water) $\mathrm{S}_{1}$ : Drainage water and well water (1:2) $\mathrm{S}_{2}$ : Drainage water and well water (2:1) $\mathrm{S}_{3}$ : Drainage water

$\mathrm{X}$ : mean, S.D.: standard deviation, *the values with identical superscripts in row are significantly different at $\mathrm{P}<0.05$ 
Table 11. Energy and protein value of maize silages NEL, NEG in MJ.kg-1 of dry matter and PDIN, PDIE in g. $\mathrm{kg}^{-1}$ of dry matter

\begin{tabular}{lccccc}
$\begin{array}{c}\text { Treatments } \\
\text { parameters }\end{array}$ & $\mathbf{S}_{\mathbf{0}}$ & $\mathbf{S 1}$ & $\mathbf{S}_{\mathbf{2}}$ & $\mathbf{S}_{\mathbf{3}}$ & S.D \\
\hline & & & $\mathrm{x}$ & & \\
\hline NEL & $5.36^{*}$ & 4.21 & 3.22 & $5.37^{*}$ & 0.03 \\
\hline NEG & 5.28 & 4.32 & 3.24 & 5.25 & 0.03 \\
\hline PDIN & 34.37 & 29.43 & 27.65 & 21.14 & 2.43 \\
\hline PDIE & 46.39 & 29.34 & 28.54 & 46.85 & 2.16 \\
\hline
\end{tabular}

NEL: net energy of lactation, NEG: net energy of gain, PDIN: protein digestible in intestine when degradable N is limiting microbial protein synthesis in the rumen, PDIE: protein digestible in intestine when rumen fermentable energy (organic matter) is limiting microbial protein synthesis in the rumen, X: mean, S.D.: standard deviation, *the values with identical superscripts in column are significantly different at $\mathrm{P}<0.05$

MJ: Millijoules/ kilogram

Table 12. Fermentation products in maize silages in $\left({\left.\mathrm{g} . \mathrm{kg}^{-1}\right)}^{-1}\right.$ of dry matter

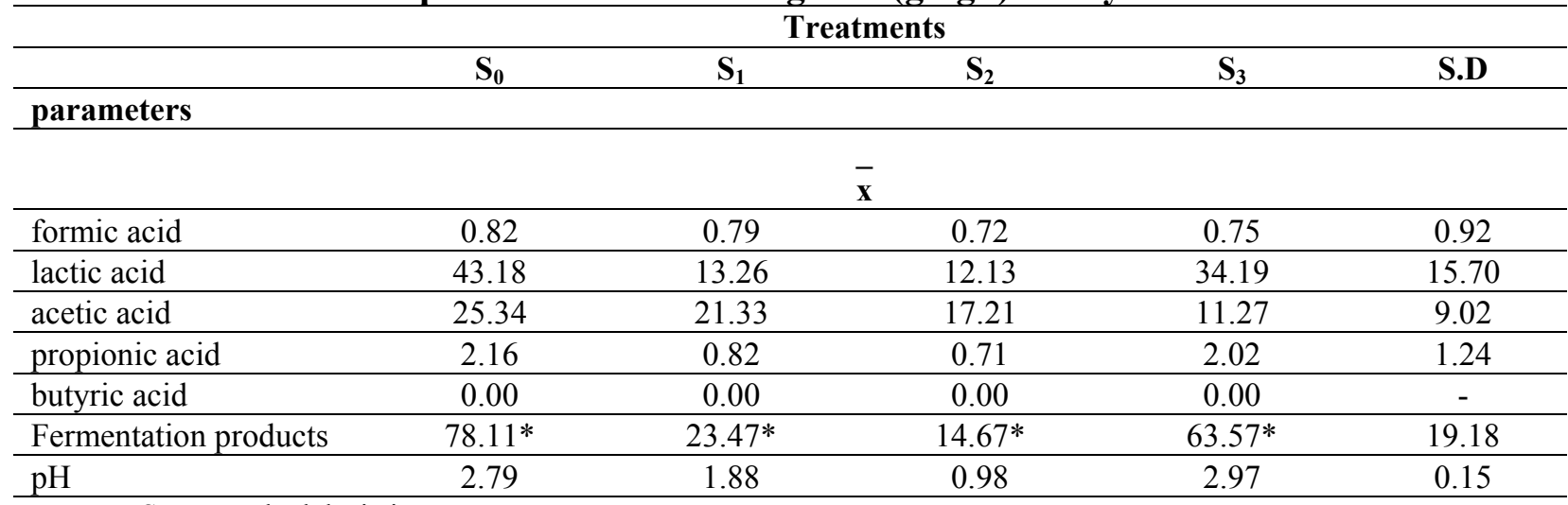

$\mathrm{x}$ : mean, S.D.: standard deviation

*the values with identical superscripts in column are significantly different at $\mathrm{P}<0.05$

\section{CONCLUSION}

From the previous data, it could be concluded that the electrical conductivity of the irrigation water (EC) affected most variables related to the growth of maize plants and types of water can be used to produce safety silages material with high quality and productivity.

These also help in reducing saline water use without treatment in maize fodder irrigation and production at the national level. Therefore, it is recommended that to study water irrigation quality and calcareous soil before forage maize planting. Acetic acid was lower in silages at different salinity levels and the values were 25.34, 21.33, 11.27 and $11.27 \mathrm{~S}_{0}, \mathrm{~S}_{1}, \mathrm{~S}_{2}$ and $\mathrm{S}_{3}$. Direct cause for reduction of maize silages quality was higher content of acetic acid.

\section{REFERENCES}

Abdelrazek S. A. E. 2014. Effect of Wastewater Irrigation on Plant Enzymes and Soil Health Assessment in Borg Elarab Region, PH.D A thesis University of Sadat City. http://t1 t.net/book/index.php?action=view\&id=2070

Ashraf, M. 2004. Some important physiological selection criteria for salt tolerance in plants Flora 199:361-367.
Baruah, T.C. and H.P. Barthakur 1997. A Textbook of Soil Analysis Vikas Publishing House PVT LTD, New Delhi.

Biro, D. 2002. Nutritional and technological factors affecting the quality and nutritive value of silage 5th Days of nutrition and Veterinary Dietetics Bratislava, SVPS, 51-56

Bohnert, H.J. and R. G. Jensen. 1996. Metabolic engineering for increased salt tolerance. The next step. Aust. J. Plant Physiol. 23: 661-667.

Bosworth, S., 2006. Corn silage quality in Vermont - 2006

Blaba, A. M. 1981. Calcareous soil properties and management Adv. In Soil and Water Res, In Alex. 1pp. 61

Chen, C., C., Tao, H. Peng, and Y. Ding. 2007. Genetic analysis of salt stress responses in asparagus bean (Vigna unguiculata L. ssp. Sesquipedalis verdc(. J. Hered., 98 (7), pp. 655-665.

Dhiman, T.R., M.A. Bal, Z. Wu, V.R. Moreira. R.D. Shaver, L.D. Satter, K.J. Shinners, R.P. Walgenbach. 2000. Influence of mechanical processing on utilization of corn silage by lactating dairy cows. J. Dairy Sci. 83, 25212528.

Donahue, R. L, R.W. Miller, and J.C. Shickluna. 1990. Soils: An introduction to soils and plant growth. Prentice-Hall of India Private limited, New Delhi 
Duncan, D. B. 1955. Multiple range and multiple F- test. Biometrics, 11: 1-42

El-Gabaly, M. M. 1971. Reclamation and management of salt affected soils. In salinity Seminar Baghdad,14 December 1970, Irrigation and Drainage .Paper No.17, F.A.O., Rome. Italy. Pp. \%0 -90.

FAO, 1970. Physical and chemical methods of soil and water analysis Soils Bulletin No.10, FAO, Rome

FAO, 1973. Irrigation, drainage and salinity: an international source book. Paris: UNESCO/Hutchinson, 510p.

FAO, 1976. Soil survey investigation for irrigation Soil Bull.42, Rome

Fathi, N.O. and A. A. Goafer. 2015. Growth performance and chemical composition of corn seedling (Zea mays L) under salt stress and priming conditions Alex .sci. Exch. J.36 (3): 226-235

Ferreira, G. 2002. Nutrient evaluation Maize silage: Chemical and Physical characteristics of Maize silage and their effects on in vitro disappearance. M.S. Thesis (Ch. 3) Univ of Wisconsin-Madison

Ferreira, G. and D. R. Mertens, 2005. Chemical and physical characteristics of Maize silages and their effects on in vitro disappearance Journal of Dairy Science

Gama, P.B.S, S. Inanaga, K. Tanaka, and R. Nakazawa. 2007. Physiological response of common bean (Phaseolus vulgaris L.) seedlings to salinity stress. Afr. J. Biotechnol., 6 (2), pp. 79-88.

Gaui FN, T .Basta, and WR Ram 1997. Wheat grain cadmium as a effected by long term fertilization and soil acidity.J.Environ.Qual.29.265-271.

Ha, E., B. Ikhajiagba, J.F. Bamidele, and E. Ogic-odia. 2008. Salinity effects on young healthy seedling of kyllingia peruviana collected from escravos, Delta state Global J. Environ. Res., 2 (2), pp. 74-88.

Hajibagheri, M. A., A. R.Yeo, T. J. Flowers, and J. C. Collins. 1989. Salinity resistance in Zea mays: fluxes of potassium, sodium and chloride. Cytoplasmic concentrations and mitochondrial membrane lipids. Plant cell Environ. 12: 753-757.

Hasegawa, P.M, R.A. Bressan, J.K. Zhu, and H.J. Bohnert 2000. Plant cellular and molecular responses to high salinity. Annual Review of Plant Biology, v.51, p.463-499

Hashem, H.A, R.A. Hassanein, and A.I. Shouman. 2013. Irrigation with industrial wastewater activates antioxidant system and osmoprotectant accumulation in lettuce, turnip and tomato plants. Ecotoxicol. Environ. Safety 95, 144152.

Hassanein, A.A. 2000. Physiological responces induced by shock and gradual salinization in rice (Oryza sativa L.) seedings and the possible roles played by glutathione treatment. Acta Bot. Hung. 42:139-159.

Houimli, S.I. M, M. Denden, and S.B. Elhadj. 2008. Induction of salt tolerance in pepper ( $\mathrm{B}^{\prime}$ or $\left.\mathrm{Hbt} \mathrm{l}^{\prime} \mathrm{mmtt}\right)$ by $24-$ epibrassinolideEurasia J. Biol. Sci., 2, pp. 83-90.
Jackson, M.L. 1958. Soil Chemical Analysis Prentic- Hall, Inc. Englewood Cliffs, N.J. Library of Congress, USA

Jamil, M., S. Rehman, and E.S. Rha. 2007a. Salinity effect on plant growth, ps11 photochemistry and chlorophyll content in sugar beet (Beta vulgaris L.) and cabbage (Brassica oleracea capitata L( Pak. J. Bot., 39 (3), pp. 753-760.

Jamil, M., S.U. Rehman, K. J. Lee, J.M. Kim, and H.K. Rha. 2007b. Salinity reduced growth ps 2 photochemistry and chlorophyll content in radishSci. Agric. (Piracicaba, Braz.), 64 (2), pp. 111-118.

Jones, C.E. 2001. Regenerative land management: a whole of landscape approach to the restoration of water balance and water quality. 'Beyond Streambank Fencing' Landcare Forum, Gloucester, NSW, December 2001

Jung, H.G., D.R. Mertens, and D.R. Buxton. 1998. Forage quality variation among maize inbreds: in vitro digestion kinetics and prediction with NIRS. Crop Science, 38, 205210.

Katerji, N. J. W. Hoorn, van A. Hamdy, F. Karam, and M. Mastrorilli, 2001. Salt tolerance of crops according to three classification methods and examination of some hypothesis about salt tolerance Agricultural Water Management, v.47, p.1-8,

Kolver, E.S., J.R. Roche, D. Miller, and R. Densley. 2001. Maize silage for dairy cows Proceedings of the New Zealand Grassland Association, 63, 195-201.

Ludemann, C.I., R.J. Eckard, B.R. Cullen, J.L. Jacobs, B. Malcolm, and K.F. Smith. 2015. Higher energy concentration traits in perennial ryegrass (Lolium perenne L.) may increase profitability and improve energy conversion on dairy farms Agricultural Systems 137 189100

Mahajan, S. and N. Tuteja. 2005. Cold, salinity and drought stresses. An overview. Archives of Biochemistry and Biophysics. 444:139-158.

Mahdy, A. M., N. O. Fathi, M.M. Kandil and A. E. Elnamas. 2012. Synergistic effects of biofertilizers antioxidant on growth and nutrients content stresses. Alex. Sci. Exch. J. 33 (4):292-304

Mathur, N., J., Singh, S. Bohra, A. Bohra, and A. Vyas. 2006. Biomass production, productivity and physiological changes in moth bean genotypes at different salinity levels Am. J. Plant Physiol., 1 (2), pp. 210-213.

Memon, S.A., X. Hou, and L.J. Wang. 2010. Morphological analysis of salt stress response of pak Choi EJEAFChe, 9 (1), pp. 248-254.

Mertens, D.R. 2005. Particle size, fragmentation index, and effective fiber: Tools for evaluating the physical attributes of Maize silages. Proc. 2005 Four-State Dairy Nutr. And Management Conf. pg 211-220.

Misra, A.N., D .Latowski, and K. Stirzalka 2006. The xanthophyll cycle activity in kidney bean and cabbage leaves under salinity stress Biomed. Life Sci., 53 (1), pp. 102-109. 
Mohamed Kamel Fattah1, S. A. E. Abdelrazek. 2014. The Improvement of the Quality of Irrigation Water Contaminated with Heavy Metals in the Borg El Arab, EgyptJournal of Water Resource and Protection, 2014, 6, 1703-1715

http://www.scirp.org/journal/articles.aspx?searchCode=Moha med+Kamel+Fattah\&searchField $=$ authors \&page $=1$

Munns, R. 2002. Comparative physiology of salt and water stress. Plant cell Environ. 25: 239-250.

Munns, R. 2005. Genes and salt tolerance: bringing them together. New Phytologist, v.167, p.645-663

Mustard, J. and S. Renault. 2006. Response of red-osier dogwood (Maizeus sericea) seedling to $\mathrm{NaCl}$ during the onset of bud break Can. J. Bot., 84 (5), pp. 844-851.

Netondo, G.W., J.C. Onyango, and E. Beck. 2004. Crop physiology and metabolism Sorghum and salinity II - gas exchange and chlorophyll fluorescence of sorghum under salt stress Crop Sci., 44 (3), pp. 806-811.

Page, A. L., R.H. Miller and R. Keeny. 1982. Methods of soil analysis. Part2. Chemical and Microbiological Properties, Agron Monograph no. 9, ASA, Madison, Wisc U. S. A.

Raul L. Raul, O. Andres, L. Armado, M. Bernardo, and T. Enrique. 2003. Response to salinity of three grain legumes for potential cultivation in arid areas (plant nutrition)Soil Sci. Plant Nutr., 49 (3), pp. 329-336.

Richards, R.L. ed. 1954. Diagnosis and improvement of saline and alkali soils. Agriculture Hand Book No.60, U.S Gover. Printing Office, Washington, USA.

Rui, L., Wei, S., Mu-xiang, C., Cheng-jun, J., Min, W. and Bo-ping, Y. (2009). Leaf anatomical changes of Burguiera gymnorrhiza seedlings under salt stress J. Trop. Subtrop. Bot., 17 (2) pp. 169-175.
Slinger, D. and K.Tenison. 2007. Salinity Glove Box Guide: NSW Murray \& Murrumbidgee Catchments, NSW Department of Primary Industries.

Summers, J.D. 2001 Maize, factors affecting its digestibility and variability in its feeding value. In: M. R., Bedford and G.G., Patridge, ed. 2001 Enzymes in farm animal nutrition. Wallingford, CABI Publishing, p.p. 109-124.

Sultana, N., T. Ikeda, R. Itoh, 2000. Effect of $\mathrm{NaCl}$ salinity on photosynthesis and dry matter accumulation in developing rice grains Environ. Exp. Bot., 42 (3), pp. 211-220.

Tenison, K. 2009. Salt Training Manual (unpub), NSW Department of Primary Industries

Tort, N. and B. Turkyilmaz. 2004. A physiological investigation on the mechanisms of salinity tolerance in some barley culture forms J.F.S., 27, pp. 1-16.

USDA, 2013. Crop production, 2012 Summary USDA, National Agricultural Statistics Service 88, 4414-4425.

Williams, D. M. 1948. A rapid manometric method for determination of carbonate in soils Soil Sci. Soc. Amer. Proc. 13: 127- 129.

WPCF, 1998. Standard Methods for the Examination of Water and Wastewater Copyright 1999 by American Public Health Association American Water Works Association, Water Environment Federation

Yazar, A. B. Gençel, M.S Sezen. 2003. Maize yield response to saline irrigation water applied with a trickle system. Food, Agriculture \& Environment, v.1, p.198-202

Yilmaz, H. A. Kina. 2008. The influence of $\mathrm{NaCl}$ salinity on some vegetative and chemical changes of strawberries (Fragaria $x$ ananassa L) Afr. J. Biotechnol., 7 (18), pp. 3299-3305.

Zhao, G.Q., B.L. Ma, and C.z. Ren. 2007. Growth, gas exchange, chlorophyll fluorescence and ion content of naked oat in response to salinity Crop Sci., 47 (1), pp. $123-131$ 


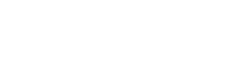

\section{الثر الرى بميله الصرف الزراعي عل إنتاجية نبلت ذرة الهل كسيلاج والمزروعف ترية جيربة}

سعد عبد الصمد للسيد عبد الرازق، لحمد البراهيم محموششومان، محمد هلثم اليب، وليد محمد بسيونى دروبش اليش

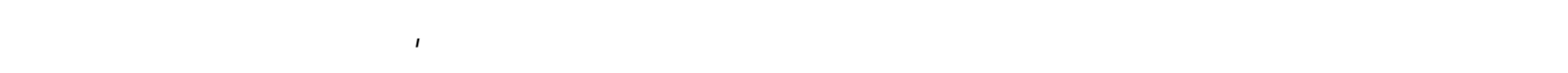

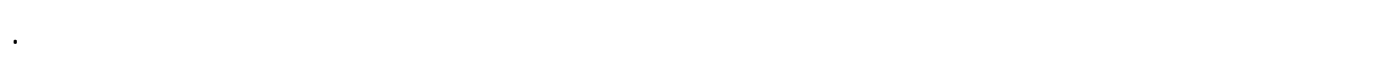

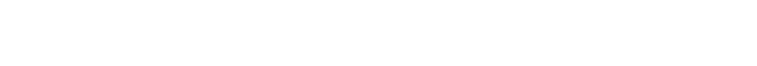
الغذائية عنطريق الذرة الرفيعة المستخمة كعلف وكسيلاج

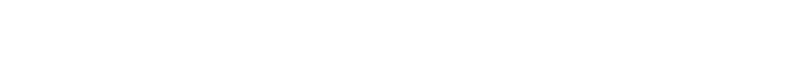
والمزروعة في ارض جيرية.

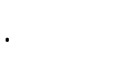
كما يؤدى إرتفاع الملوحة وترلم العناصر اللى خف ـض الإن

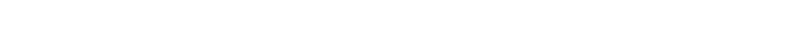

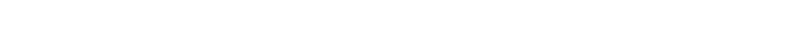
ترتيبها فى المعلملات كالتالي تعالي وفى النهاية تنخضض كمية حمض الخليك كمؤشر هـ هلم

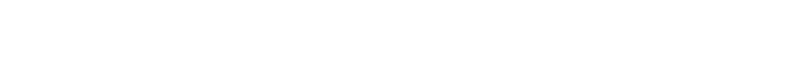

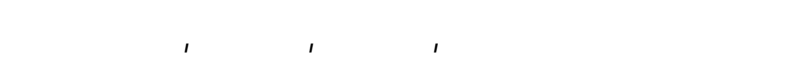

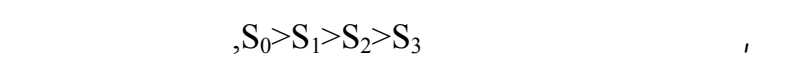
وللسب المبلثر لموء جودة للسيلاج على وجه الخصوص

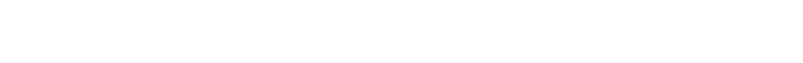

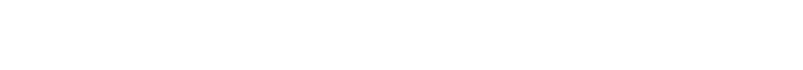
إلى ترلمم مجموع الأملاح الذائبة في التربة. الكلمك الدليلية: ميه الصرف الزراعي، ميه الارتوازي علف الملثية، للسيلاج، أراض الجيرية. يعتبر ارتفاع تركيز الصويوم والكلوريد ف وي محل ـول التربة ويعتبر للسب الرئيسي للإجهاد الملجي، ويترتب عله ذلك بط النمو، وظهور التكيف لمقاومة الإجهاد الملح ي، المئي وتعتمد النباتات علىطرق متعدة من لجل مقاومة الإجهاد.

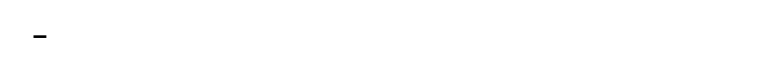

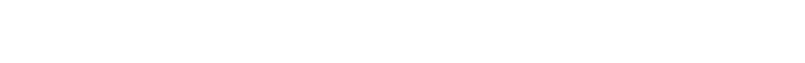
التربة بها ارفاع نسبة كربونات الكلاسيوم وق 2 وج وج 2 أن

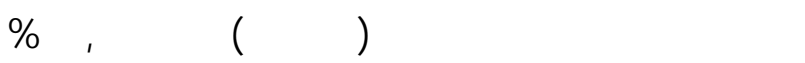

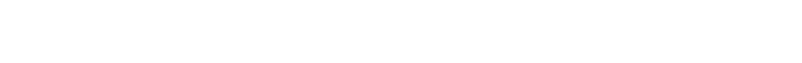

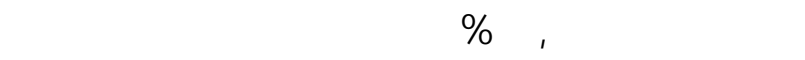

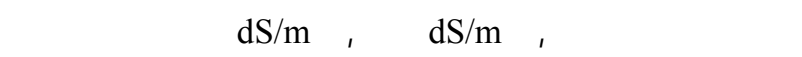

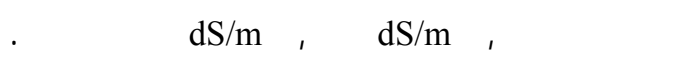
ولظهرت النتائج ارتف اع ق يم عن صرى الفوس فور والبوتلسيوم فى اوراق النباتلت ووجود فروق معنوية بـ بـن المعلملات وخاصة فى العناصر الغذائية الصغرى وذلك عند 